\title{
Critically Endangered Fijian Crested Iguana (Brachylophus vitiensis) Shows Habitat Preference for Globally Threatened Tropical Dry Forest ${ }^{1}$
}

\author{
Clare Morrison, ${ }^{2,4}$ Gunnar Keppel, ${ }^{4}$ Nunia Thomas, ${ }^{3}$ Isaac Rounds, ${ }^{3}$ and Peter S. Harlow ${ }^{5}$
}

\begin{abstract}
Tropical dry forests are a unique and threatened ecosystem in the Pacific and globally. In Fiji, the endangered Fijian crested iguana (Brachylophus vitiensis) is endemic to tropical dry forests. Yadua Taba Island contains one of the best remaining stands of tropical dry forest in the Pacific along with the largest (and only secure) population of B. vitiensis in Fiji and has been proposed as a translocation source for iguana conservation. In this study we determined the major vegetation types on Yadua Taba and identified forest habitat preferences of B. vitiensis to (1) characterize the island's habitats for tropical dry forest regeneration monitoring and (2) understand which forest types are preferred by iguanas for future translocation projects. Vegetation data were collected using reconnaissance, entitation, line transects, and aerial photos. Iguana abundance data were collected by nocturnal surveys of permanent transects. Six major vegetation types were identified of which tropical dry forest was the largest (46\% of the island), followed by a combination of rocky cliff-shrubland/grassland vegetation (26\%). Our conservative estimate of B. vitiensis population size on Yadua Taba is 12,000 iguanas, the majority of which occur in tropical dry forest. Superabundance of the dry forest understory tree Vavaea amicorum, the favorite fruit species of iguanas, may help account for the high density of iguanas observed. These results highlight the ecological link between tropical dry forest and $B$. vitiensis and emphasize the importance of rehabilitation or conservation of tropical dry forest habitat in potential iguana translocation sites as part of the management plan for B. vitiensis throughout the Fiji Islands.
\end{abstract}

${ }^{1}$ The first plant survey in 2002 was funded by the Wildlife Conservation Society (WCS). The iguana surveys were funded by an Australia and Pacific Scientific Foundation (APSF) grant to C.M. Manuscript accepted 15 May 2008.

${ }^{2}$ Corresponding author.

${ }^{3}$ Institute of Applied Sciences, University of the South Pacific, Suva, Fiji.

4 Centre for Innovative Conservation Strategies, School of Environment, Griffith U niversity Gold C oast, Q ueensland 4222, Australia

(e-mail: claremorrison.grignon@gmail.com).

$5 \mathrm{C} / 0 \mathrm{H}$ erpetofauna D ivision, T aronga Zoo, P.O. Box 20, M osman, N ew South W ales 2088, Australia.

Pacific Science (2009), vol. 63, no. 2:223-242

(C) 2009 by University of Hawai'i Press

All rights reserved
TROPICAL DRY FOREST generally occurs in seasonally dry tropical regions where the average annual rainfall is less than $2,000 \mathrm{~mm}$. In addition, tropical dry forests usually experience dry seasons (monthly rainfall $<100$ $\mathrm{mm}$ ) that stretch over 3 months or more (Mooney et al. 1998). In the Pacific, tropical dry forest has been recorded from Australia, New Guinea, the Solomon Islands, Vanuatu, New Caledonia, Fiji, and Hawai'i (Keppel and Tuiwawa 2007). Due to a combination of factors including fire, grazing by goats, introduction of invasive plant species, and clearing for agriculture (e.g., sugarcane, coconut, and pineapple plantations), very few, usually small, patches of tropical dry forest remain in tropical dry areas. As such, tropical dry forests are now considered one of the most endangered tropical ecosystems globally (Janzen 1988, Lerdau et al. 1991) and in the 
Pacific (Keppel 2005, Keppel and Tuiwawa 2007).

Fijian tropical dry forest is restricted to the western, rain-shadow side of high islands and smaller offshore islands, where rainfall is low and droughts commonly occur. Most plant species occurring in Fijian tropical dry forest are widespread; however, approximately onethird are endemic to Fiji and several are endemic to Fijian tropical dry forest (Keppel and Tuiwawa 2007). Although little is known about the ecology of this ecosystem in Fiji, most Fijian tropical dry forest has been substantially degraded through clearing and the introduction of exotic species, with only a few, very small remnants of true tropical dry forest remaining. However, despite its uniqueness, rarity, and ongoing decline in both extent and quality, Fijian tropical dry forest is not listed as threatened or endangered under national legislation.

One of the best examples of tropical dry forest in Fiji and in the Pacific is found on Yadua Taba Island, a National Trust of Fiji Reserve in the northwest of Fiji. Over the past $25 \mathrm{yr}$, goats have been removed from the island, fires have been banned, and anthropogenic activities greatly restricted, which have increased the extent and improved the condition of tropical dry forest on Yadua Taba. In addition to having the only protected tropical dry forest in Fiji, Yadua Taba also supports the largest and only legally protected population of the critically endangered Fijian crested iguana, Brachylophus vitiensis Gibbons.

The endemic $B$. vitiensis is an herbivorous lizard restricted to tropical dry forest and similar habitats on islands in western Fiji (Gibbons 1981, 1984) and is part of a monophyletic lineage that includes the Lauan banded iguana (B. fasciatus), the Fijian banded iguana (B. bula bula) and at least two extinct species (Pregill and Steadman 2004, Keogh et al. 2008). It is currently listed as Critically Endangered under IUCN (2006) criteria and is the only Fijian reptile listed as Endangered in the Fiji National Biodiversity Strategy and Action Plan (NBSAP 1998). Over the past 20 $y r$ it has been extirpated from almost $80 \%$ of its documented range primarily due to exten- sive destruction of its habitat (through fire and goat grazing) and, to a lesser extent, predation by cats, dogs, and mongooses. Currently only Yadua Taba and another small island, Macuata, harbor viable populations. The Macuata population is small, consisting of $<80$ individuals (Harlow et al. 2007), and Yadua Taba is the stronghold for the species, containing >6,000 individuals (Harlow and Biciloa 2001). All other populations are extremely small and likely doomed because of continued tropical dry forest habitat loss due to clearing, grazing by goats, fire, invasive plants, and predation (Harlow et al. 2007).

Although the population of $B$. vitiensis on Yadua Taba is currently thriving and secure, it is still vulnerable to the accidental introduction of exotic predators, disease, wildfire, invasive alien plant species, and natural hazards such as tropical cyclones, which are capable of decimating the population. As such, translocations of iguanas from Yadua Taba to other suitable islands within the former range of $B$. vitiensis have been proposed as a viable conservation management option for the species (IUCN Species Survival Commission 2008).

There are a number of factors associated with successful translocations including habitat quality or suitability: translocations into areas of high habitat quality or suitability are demonstrably more successful than those to areas that are of lower quality or are less suitable (Griffith et al. 1989, Bright and Morris 1994, Fischer and Lindenmayer 2000). However, to identify suitable translocation sites or restore habitat for successful species recovery, we need to have a good understanding of the habitat requirements and preferences of the focal species.

Although we have some knowledge of the habitat and vegetation preferences of $B$. vitiensis, this work has been largely opportunistic in nature (with the exception of Harlow and Biciloa [2001] and Harlow et al. [2007]). A previous study of $B$. vitiensis on Yadua Taba demonstrated that iguanas were primarily found in forest vegetation, were not found in nonnative forest types including grasslands, and were observed in very low abundance in rocky-cliff or shrubland vegetation (Harlow and Biciloa 2001). 
The overall aims of the project were to determine the major vegetation types present on Yadua Taba and quantify the forest habitat preferences of $B$. vitiensis to (1) characterize the vegetation types on Yadua Taba for tropical dry forest regeneration monitoring and (2) identify the most suitable forest habitats for future iguana translocation projects. Specifically, the objectives were to (a) identify the major vegetation types on Yadua Taba and map their current distribution, (b) determine the extent of tropical dry forest regeneration on Yadua Taba, (c) compare the plant species diversity of Yadua Taba tropical dry forest with that on other Fijian islands, and (d) estimate iguana abundance and density in the different forest types and identify their preferred habitat(s). The results of this research will be used to provide a baseline to monitor future tropical dry forest reforestation or regeneration on Yadua Taba as well as provide essential ecological data for future iguana translocation programs.

\section{MATERIALS AND METHODS}

\section{Study Site}

Yadua Taba is a small (73 ha), uninhabited volcanic island located in the northwest of the Fiji Islands $\left(16^{\circ} 50^{\prime} \mathrm{S}, 178^{\circ} 20^{\prime} \mathrm{E}\right)$. It reaches $120 \mathrm{~m}$ in height and lies $120 \mathrm{~m}$ off the much larger inhabited island of Yadua (1,360 ha). In 1972 goats were introduced to Yadua Taba and numbered over 200 by the late 1970s (Gibbons 1984). The tropical dry forest vegetation on the island during that time was severely depleted by a combination of grazing and fire used to drive goats for ease of capture. Since the island was declared a sanctuary in 1981 fires have been banned. Goats have been eradicated from the island, with most individuals removed between 2000 and 2001 and the last individual removed in 2003. Today the forest on the island has recovered to a remarkable extent and is currently one of the best remaining examples of tropical dry forest and coastal strand vegetation in the Pacific (Olson et al. 2002).

On Yadua Taba the dry season generally lasts from May to October, though in drought years it has lasted from May to January. Air temperature ranges from a minimum of $16^{\circ} \mathrm{C}$ in July-August to a maximum of $31^{\circ} \mathrm{C}$ in January-February (Gibbons 1984).

\section{Fijian Crested Iguana (Brachylophus vitiensis)}

The Fijian crested iguana is a herbivorous, diurnal, and strongly arboreal species (Morrison 2003). It is a moderately sized iguana (adults 185-236 $\mathrm{mm}$ snout-vent length [SVL], hatchlings $83-88 \mathrm{~mm}$ SVL) in which the sex of adults is easily distinguished by the presence of enlarged femoral pores in males (Morrison 2003). Reproductive cycles are poorly known; however the mating season on Yadua Taba appears to run from December to March, and gravid females are seen from January to April (S. F. Morrison, Australian National University, unpubl. data, 2006). Females dig burrows on the forest floor, where three to five eggs are laid and the burrow is then filled in. Eggs hatch roughly 8-9 months later (October-November) at the onset of the wet season (S. F. Morrison, Australian National University, unpubl. data, 2006).

\section{Plant Surveys/Vegetation Surveys}

During the first trip, from 23 to 25 March 2002, plant species were identified and vegetation types classified using the processes of reconaissance and entitation (MuellerDombois and Ellenberg 2002). The island was surveyed by walking around it during low tides and visiting each different vegetation type. We spent a minimum of $1 \mathrm{hr}$ walking through each preliminary vegetation type, recorded all the plant species encountered (presence/absence), and noted the presence of iguanas or their feeding marks (on leaves) in each vegetation type. In addition, we set up a $10 \mathrm{~m}$ wide belt transect across the island (transect length approx. $500 \mathrm{~m}$ ), mostly covering tropical dry forest, to determine forest composition following Gentry (1988). This Gentry transect consisted of 10 smaller transects $(50 \times 2 \mathrm{~m})$, spaced $10 \mathrm{~m}$ apart.

Because iguanas appeared to be almost exclusively restricted to forested areas (Harlow 
and Biciloa 2001), we established six line transects $(250 \times 10 \mathrm{~m})$ during our second trip, from 12 to 22 September 2005; two in each putatative tropical dry forest subtype: tropical dry forest, coastal tropical dry forest (tropical dry forest with high abundance of coastal vegetation species), and Casuarina forest with abundant tropical dry forest understory. In these transects the abundance of all tree species was recorded, and they were categorized as either canopy or understory species.

During both trips, species were identified in the field where possible. Species that could not be identified in the field samples were collected and identified at the South Pacific Regional Herbarium (SUVA) using Smith (1979-1991). Data from both surveys were combined to produce a comprehensive plant list for the island (see Appendix).

\section{Habitat Mapping}

We used a MobileMapper Pro (Thales Navigation) to map the following vegetation types on Yadua Taba: tropical dry forest, coastal vegetation, coastal tropical dry forest (areas in tropical dry forest with high abundance of coastal vegetation species), Casuarina forest (areas in shrubland/grassland dominated by Casuarina equisetifolia), rocky cliff and shrubland/grassland combined, and Leucaena leucocephala forest. The mobile mapper was used while walking around the edge of each vegetation type to delineate and accurately plot habitat boundaries. Casuarina forest was mapped separately from shrubland/grassland vegetation, because two iguana transects (described in the next section) were exclusively in this habitat type. We mapped the rocky-cliff vegetation and the remaining shrubland/grassland vegetation as a combined habitat because there were no iguana transects in either of those vegetation types and because they were always adjoining.

\section{Iguana Surveys}

TRANSECT SETUP AND SURVEY DATES. In September 2005 we set up six permanent
$250 \mathrm{~m}$ long transects in the three forest habitat types: two transects in each of tropical dry forest, coastal tropical dry forest, and Casuarina forest. We focused on forest habitats because other vegetation types had few or no iguanas in them (Harlow and Biciloa 2001, Harlow et al. 2007). Each transect was surveyed once on each of four survey trips: 12-23 September 2005 (referred to herein as September), 28 November-9 December 2005 (December), 20 February-3 March 2006 (February), and 29 May-9 June (June). Based on our previous fieldwork, these survey times were chosen to reflect major seasonal differences in weather and plant phenology. We did not set up transects in the rocky-cliff-shrubland/grassland vegetations because they consisted mainly of grassland and low shrubs (not favored by iguanas [Harlow and Biciloa 2001]) or in the introduced $L$. leucocephala patches because they were too small to accommodate a $250 \mathrm{~m}$ transect (also not favored by iguanas [Harlow and Biciloa 2001]). True coastal vegetation was also not surveyed due to the small size of the habitat.

Transect surveys. We used line transects (Harlow and Biciloa 2001) for the iguana surveys. Although the iguanas are diurnal animals, they are extremely cryptic and difficult to observe during the day. They are easier to spot at night while sleeping on horizontal branches because their pale ventral surface contrasts markedly with the surrounding vegetation. Iguanas were clearly visible up to 20 $m$ high even in relatively thick vegetation. Each night four searchers (two on either side of the central line) with strong torches surveyed all iguanas along the transect line. We searched all trees, shrubs, and vine mats up to $25 \mathrm{~m}$ high paying particular attention to those directly above the line. On each side of the transect line one searcher walked roughly $1 \mathrm{~m}$ from the line while the other walked roughly 4-5 $\mathrm{m}$ from the line. This allowed us to search for iguanas from a wider range of angles as well as directly above the line. For each iguana observed we recorded its perpendicular distance to the central line (to nearest $0.1 \mathrm{~m}$ ) using tape measures and estimated its height to the nearest $0.5 \mathrm{~m}$. 
Analyses

vegetation. All species were classified as either endemic, indigenous, or recently introduced to Fiji. Presence/absence data for the various vegetation types were used to create a Bray-Curtis similarity matrix, which was used for nonmetric multidimensional scaling with 200 restarts using PRIMER 5 (Clarke and Gorley 2001).

The frequency of species in the Gentry transect was used as an estimate of their abundance, and the diameter at breast height (dbh) was used to calculate the basal area (basal area $=\pi\left[\begin{array}{ll}\frac{1}{2} & \mathrm{dbh}\end{array}\right]^{2}$ ) as an estimate of their relative dominance. The data were then compared with those of similar transects in Fiji (T. W. Gillespie, unpubl. data).

Abundance data from the six $250 \times 10 \mathrm{~m}$ transects were divided into canopy trees and understory trees after introduced species had been removed. Introduced species were excluded from the analysis because they are not exclusive to different habitat types and were often found in all vegetation types to various extent. Canopy and understory data were subjected to nonmetric multidimensional scaling based on Sorensen similarity using the Community Analysis Package 2.15 (Henderson and Seaby 2002). We tested the null hypothesis that there are no significant differences between the three vegetation subtypes (tropical dry forest, coastal tropical dry forest, and Causarina forest) for all data sets (canopy, understory, and combined) by analysis of similarity (ANOSIM) using PRIMER 5 (Clarke and Gorley 2001). The sample statistic (Global $R$ ) produced during ANOSIMs is similar to that of the Pearson Correlation Coefficient $(R)$. If Global $R=0$, the groups are completely similar, if Global $R=1$, the groups are completely dissimilar. The ANOSIM was conducted on a square-root transformed Bray-Curtis similarity matrix with 999 permutations.

HABITAT AREA. Using the Geographic Information System (GIS) data from on-theground mapping, aerial photos, and the computer program Corel Draw 12.0, we generated a habitat map of Yadua Taba and calculated the area of occurrence of each habitat type. This was done by using the aerial photo to provide the outline area of the island, and the GIS data were used to overlay habitat boundaries on this outline. We used Corel Draw to calculate the area of each habitat type.

IgUANA ABUNDANCE EStimates. We used the computer program Distance 4.1 (Thomas et al. 2004) to fit detection functions and determine iguana abundance per hectare for each of the forest types studied based on transect counts. We analyzed the data from each transect and trip separately. We then estimated the total number of crested iguanas on the entire island by multiplying the average calculated densities of iguanas for each vegetation type by the area of those habitats available. As we resurveyed the same transects each time on Yadua Taba, iguana abundance and density in each forest habitat were compared using repeated measures Analyses of Variance (ANOVAs). SPSS Version 13.0 was used for the analyses and $\alpha$ was set at 0.05 .

\section{RESULTS}

\section{Vascular Plant Flora}

A total of 140 vascular plant species was identified during the survey. Indigenous vascular plants on the island made up $79 \%$ (110 species) of the flora. Fifteen species (14\% of the indigenous flora) are endemic, most of which are relatively common in Fiji. Cynometra falcata, Croton metallicus, and Excoecaria acuminata, however, are restricted to Fiji's dry zone.

Seven of the invasive plants present, Mikania micrantha, Sphagneticola trilobata, Samanea saman, Passiflora foetida, L. leucocephala, Annona glabra, and Lantana camara, are of concern, because these may establish in natural vegetation (Meyer 2000). The remaining invasive species are usually restricted to disturbed vegetation.

\section{Vegetation Types}

Six major vegetation types (and several subtypes) were identified based on the dominant canopy species (Figure 1, Table 1): (1) coastal 


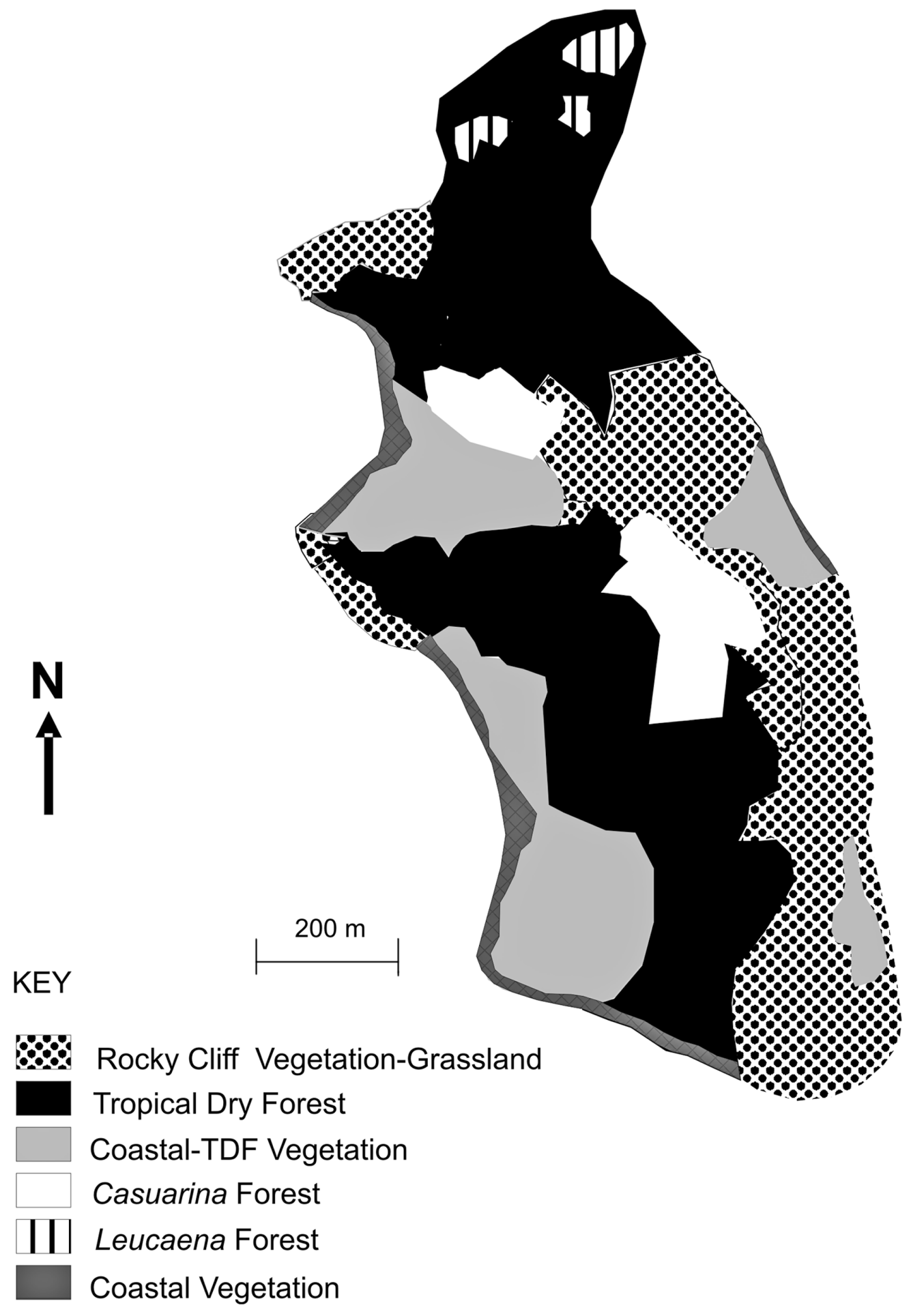

Figure 1. Vegetation map of Yadua Taba. 


\section{TABLE 1}

Summary of Species Richness, Dominant Species, and Observed Presence of Iguanas in the Vegetation Types on Yadua Taba

\begin{tabular}{|c|c|c|c|}
\hline Vegetation Type & $\begin{array}{c}\text { No. of } \\
\text { spp. }\end{array}$ & Dominant spp. & Iguanas? \\
\hline
\end{tabular}

1. Coastal vegetation

(a) Beaches

58

(b) Rocky shores

63

2. Rocky-cliff vegetation

13

3. Tropical dry forest

(a) Inland

(b) Coastal

4. Casuarina forest

(a) Grass understory

(b) Tropical dry forest understory

5. Grasslands

(a) Pennisetum-dominated

(b) Miscanthus-dominated

6. Leucaena forest
Herbaceous zone: Stenotaphrum micranthum, Thuarea involuta, Lepturus repens, Vigna marina, Ipomoea macrantha, Ipomea pes-caprae, Canavallia sericea; shrub zone: Colubrina asiatica, Clerodendron inerme, Vitex trifolia, Scaevola taccada, Eugenia reinwardtiana, Acacia simplex; forest zone: Neisosperma oppositifolia, Terminalia spp., Millettia pinnata, Cocos nucifera, Hibiscus tiliaceus, Thespesia populnea, Planchonella grayana, Calophyllum inophyllum, Guettarda speciosa

Herbaceous zone: Mariscus javanicus, Fimbristylis dichotoma; shrub zone: Xylocarpus moluccensis, Dendrolobium umbellatum, Clerodendron inerme; forest zone: Calophyllum inophyllum, Excoecaria agallocha, Homalium vitiense, Guettarda speciosa, Thespesia populnea, Planchonella grayana (understory: Casearia richii, Excoecaria acuminata, Hibiscus tiliaceus; climber: Derris trifoliata)

Shrubs: Croton metallicus, Ficus tinctoria, Clerodendron inerme, Maesa tabacifolia, Solanum viride, Vitex trifolia; herbs: Botbriochloa bladbii, Cheilanthes birusta, Elaeocharis geniculata, Digitaria radicosa, Oxalis corniculata

Canopy: Gyrocarpus americanus, Erythrina variegata, Millettia pinnata, Ficus obliqua, F. prolixa, Kingiodendrum platycarpum, Cynometra insularis, Planchonella grayana, Pittosporum brackenridgei, Drypetes vitiensis (subcanopy: Vavaea amicorum, Mallotus tiliifolius, Diospyros elliptica, Micromelum minutum, Antirbea inconspicua; climbers: Ventilago vitiense, Pteris ensiformis, Cheilanthes hirsuta)

Similar to 3(a) but Cordia subcordata, Erythrina variegata, Psydrax odorata common, and Ficus obliqua, F. prolixa, Kingiodendrum platycarpum, Drypetes vitiensis, and Antirhea inconspicua are absent or rare

Canopy: Casuarina equisetifolia; herbs: Pennisetum polystachion

Canopy: Casuarina equisetifolia, Glochidion vitiense, Tabernaemontana pandacaqui, Micromelum minutum, Vavaea amicorum

Yes (forest)

Yes (forest)

No

Yes

Yes

No

Yes

Leucaena lecocephala 


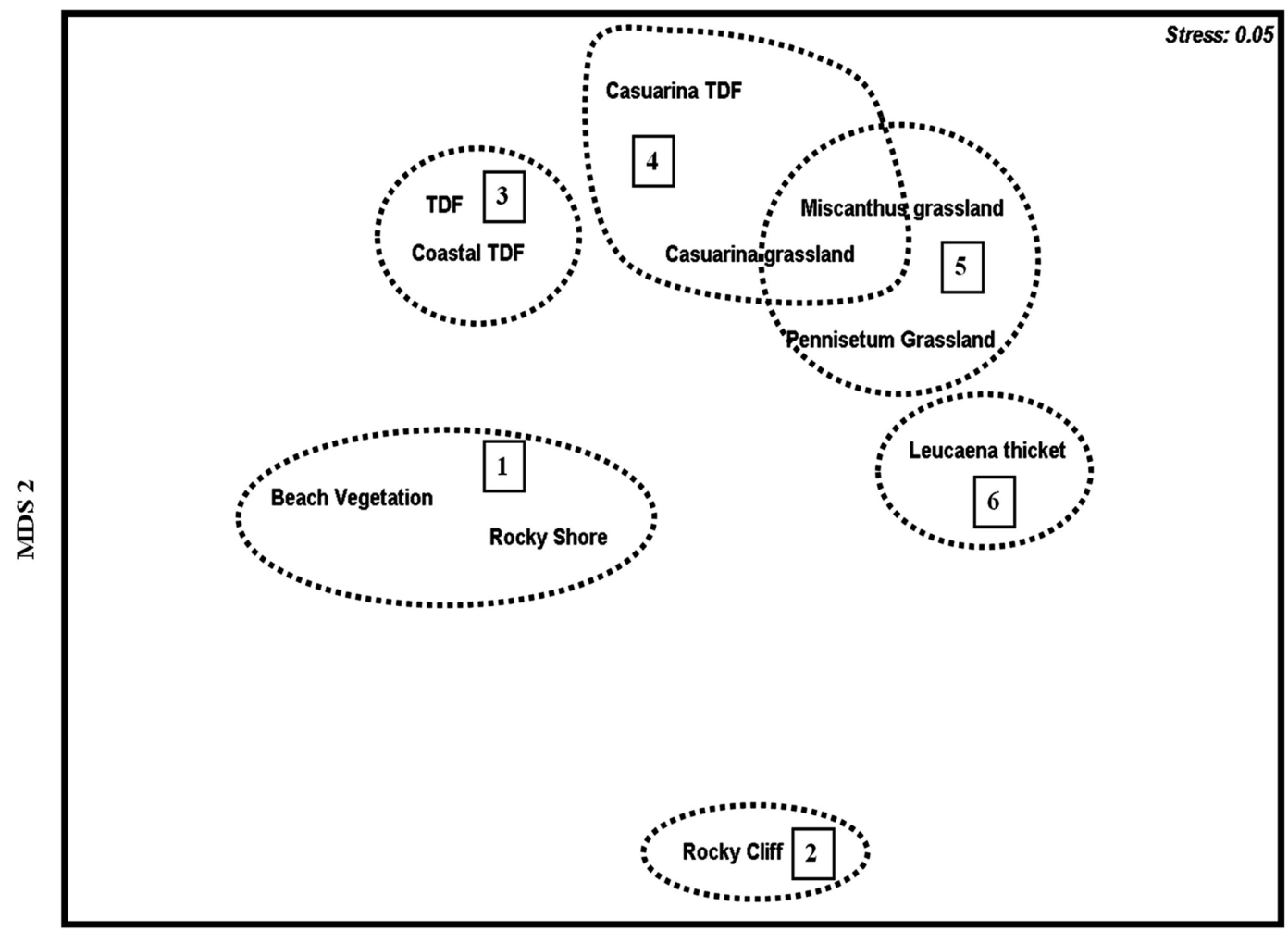

MDS 1

Figure 2. Nonmetric multidimensional scaling plots of transects using presence/absence data from the various vegetation types. 1, Coastal vegetation (including sandy beach and rocky-shore vegetation); 2, rocky-cliff vegetation; 3, tropical dry forest (including coastal and inland tropical dry forest); 4, Casuarina forest (including Casuarina forest with grassland and tropical dry forest understory); 5, grasslands (including those dominated by Pennisetum polystachion and those dominated by Miscanthus floridulus); 6, Leucaena lecocephala shrubland.

vegetation, (2) rocky-cliff vegetation, (3) tropical dry forest (including true tropical dry forest and coastal tropical dry forest), (4) Casuarina forest, (5) shrubland/grasslands, and (6) Leucaena forest. These vegetation types generally form separate clusters on the nonmetric multidimensional scaling plot (Figure 2), although there was some overlap between the shrubland/grasslands and the Casuarina forest with grassland understory.

Yadua Taba's coastal vegetation does not differ much from that found on nearby smaller islands (Mueller-Dombois and Fosberg 1998, Ghazanfar et al. 2001). On sandy beaches, the three zones (herbaceous, shrub, and forest) are well developed, but on rocky shores this horizontal stratification is much less pronounced than on sandy beaches and almost entirely lacking in some areas. On rocky cliffs, which had a limited number of species, plant species adapted to harsh conditions were observed (e.g., C. metallicus and Elaeocharis geniculata).

Two types of grasslands with occasional shrubs were present: one dominated by Miscanthus floribundus and the other by Pennisetum polystacbion. At the northern end of the island, L. leucocephala formed almost pure stands in some locations, reaching $7 \mathrm{~m}$ in height.

The tropical dry forest reaches $15-20 \mathrm{~m}$ in height, with the canopy dominated by deciduous trees (e.g., Gyrocarpus americanus, Erythrina variegata, Millettia pinnata), strangler figs 
TABLE 2

Basal Area and Abundance of Plant Species in the Gentry Transect (500 m Belt Transect Composed of $10 \times 50 \mathrm{~m}$ Subtransects in Tropical Dry Forest)

\begin{tabular}{|c|c|c|}
\hline Species & $\begin{array}{c}\text { Basal Area } \\
\left(\mathrm{m}^{2}\right)\end{array}$ & Abundance \\
\hline Mallotus tiliifolius & 1.1527 & 61 \\
\hline Gryrocarpus americanus & 1.0005 & 11 \\
\hline Erythrina variegata & 0.9164 & 5 \\
\hline Vavaea amicorum & 0.7818 & 131 \\
\hline Premna protrusa & 0.1412 & 1 \\
\hline Antirbea inconspicua & 0.1116 & 5 \\
\hline Drypetes vitiensis & 0.0995 & 1 \\
\hline Diospyros phlebodes & 0.0861 & 11 \\
\hline Glochidion vitiense & 0.0840 & 1 \\
\hline Psydrax odorata & 0.0357 & 4 \\
\hline Micromelum minutum & 0.0186 & 18 \\
\hline Capparis quiniflora & 0.0107 & 5 \\
\hline Derris trifoliata & 0.0099 & 6 \\
\hline Morinda citrifolia & 0.0075 & 1 \\
\hline Lantana camara & 0.0105 & 9 \\
\hline Tabernaemontana pandacaqui & 0.0044 & 4 \\
\hline Mucuna gigantea & 0.0029 & 3 \\
\hline Planchonella grayana & 0.0013 & 1 \\
\hline Ficus barclayana & 0.0007 & 1 \\
\hline
\end{tabular}

(e.g., Ficus obliqua), and nondeciduous species (e.g., Kingiodendrum platycarpum, Cynometra insularis, Planchonella grayana, Pittosporum brackenridgei, Drypetes vitiensis). Gyrocarpus americanus, E. variegata, Mallotus tiliifolius, and Vavaea amicorum contributed about $86 \%$ of the total basal area in the Gentry transect (Table 2). The latter two species are understory species (and contributed about $69 \%$ of all stems), and the former two are canopy species. In the six line transects other species, some of which were not encountered in the Gentry transect, were also abundant (Table $3)$. Near the coast, species associated with coastal vegetation (e.g., Cordia subcordata, E. variegata, Psydrax odorata) are important elements, forming a vegetation subtype that is here called coastal tropical dry forest (Table 3). A total of 277 individual plants belonging to 19 species (15 trees and four lianas) with an extrapolated average basal area of $0.48 \mathrm{~m}^{2}$ $\mathrm{ha}^{-1}$ was encountered in the Gentry transect. Near the main ridge of the island $C$. falcata is locally common.

Casuarina forests often form a link be-
TABLE 3

Abundance of Common Trees and Shrubs in Tropical Dry Forest (TDF), Coastal TDF, and Casuarina Forest

\begin{tabular}{|c|c|c|c|}
\hline Species & TDF $a$ & $\begin{array}{l}\text { Coastal } \\
\text { TDFa }\end{array}$ & $\begin{array}{c}\text { Casuarina } \\
\text { Forest }^{a}\end{array}$ \\
\hline Casearia richii & + & + & 0 \\
\hline Casuarina equisetifolia & $\mathrm{x}$ & 0 & ++ \\
\hline Cocos nucifera & $\mathrm{x}$ & 0 & + \\
\hline Cordia subcordata & 0 & + & 0 \\
\hline Cordyline fruticosa & + & 0 & 0 \\
\hline Cynometra insularis & ++ & + & 0 \\
\hline Decaspermum vitiense & + & ++ & $\mathrm{x}$ \\
\hline Diospyros spp. & +++ & +++ & +++ \\
\hline Erythrina variegata & 0 & $\mathrm{x}$ & 0 \\
\hline Eugenia reinwardtiana & ++ & + & $x$ \\
\hline Ficus barclayana & 0 & + & 0 \\
\hline Ficus obliqua & 0 & 0 & + \\
\hline Glochidion vitiense & + & + & ++ \\
\hline Gyrocarpus americanus & + & + & ++ \\
\hline Hibiscus tiliaceus & + & 0 & 0 \\
\hline Kingiodendrum platycarpum & + & + & 0 \\
\hline Mallotus tiliifolius & + & +++ & + \\
\hline Melochia degeneriana & + & $\mathrm{x}$ & $\mathrm{x}$ \\
\hline Micromelum minutum & +++ & +++ & +++ \\
\hline Millettia pinnata & + & $\mathrm{x}$ & + \\
\hline Pittosporum brackenridgei & + & $\mathrm{x}$ & $\mathrm{x}$ \\
\hline Planchonella grayana & ++ & 0 & $\mathrm{x}$ \\
\hline Premna protrusa & 0 & $\mathrm{x}$ & $\mathrm{x}$ \\
\hline Psydrax odorata & $\mathrm{x}$ & +++ & + \\
\hline $\begin{array}{l}\text { Tabernaemontana } \\
\text { pandacaqui }\end{array}$ & + & ++ & +++ \\
\hline Terminalia catappa/litoralis & + & $\mathrm{x}$ & $\mathrm{x}$ \\
\hline Thespesia populnea & 0 & $\mathrm{x}$ & $\mathrm{x}$ \\
\hline Vavaea amicorum & +++ & +++ & +++ \\
\hline
\end{tabular}

$a+++$, superabundant ( $>100$ individuals); ++ , abundant (50-100 individuals); + , common (10-49 individuals); $x$, uncommon ( $<10$ individuals); 0 , absent.

tween the tropical dry forest and scrubland/ grassland vegetation. These forests range from almost pure, dense stands of $C$. equisetifolia to more widely spaced $C$. equisetifolia canopy with an understory of the grass $P$. polystachion (Casuarina woodland) to C. equisetifolia canopy with a subcanopy or understory of tropical dry forest species, including Tabernaemontana pandacaqui, $V$. amicorum, Micromelum minutum, and Glochidion vitiense. High abundance of $C$. equisetifolia and T. pandacaqui differentiate Casuarina forest (with tropical dry forest species undergrowth) from tropical dry forest and coastal tropical dry forest (Table 3). 
TABLE 4

Number of Iguanas Sighted per $250 \mathrm{~m}$ Transect and Iguana Density Estimates (per ha, with 95\% Confidence Intervals) for Each Transect on Yadua Taba (Also Included Are Coordinates of Starting Point of Each Transect and Direction)

\begin{tabular}{lllllrl}
\hline \hline Transect $^{a}$ & Sep. 2005 & Dec. 2005 & Feb. 2006 & Jun. 2006 & Average & Lat./Long. (Direction) \\
\hline TDF1 & 59 & 79 & 67 & 54 & 67.3 & $16^{\circ} 50^{\prime} 13.38^{\prime \prime} \mathrm{S}$ \\
& 213.0 & 242.7 & 311.0 & 224.1 & 247.6 & $178^{\circ} 16^{\prime} 38.36^{\prime \prime} \mathrm{E}$ \\
& $(152-299)$ & $(181-325)$ & $(226-428)$ & $(123-410)$ & & $\left(115^{\circ} \mathrm{E}\right) \mathrm{l}$ \\
TDF2 & 100 & 104 & 97 & 76 & 94.3 & $16^{\circ} 50^{\prime} 7.51^{\prime \prime} \mathrm{S}$ \\
& 247.2 & 235.1 & 310.1 & 299.2 & 272.8 & $178^{\circ} 16^{\prime} 35.89^{\prime \prime} \mathrm{E}$ \\
& $(183-334)$ & $(177-313)$ & $(209-461)$ & $(219-410)$ & & $\left(115^{\circ} \mathrm{E}\right)$ \\
$\mathrm{CA1}$ & 28 & 11 & 20 & 16 & 18.0 & $16^{\circ} 50^{\prime} 0.65^{\prime \prime} \mathrm{S}$ \\
& 94.1 & 37.7 & 54.8 & 40.5 & 56.8 & $178^{\circ} 16^{\prime} 42.41^{\prime \prime} \mathrm{E}$ \\
$\mathrm{CA} 2$ & $(55-160)$ & $(15-94)$ & $(27-107)$ & $(20-81)$ & & $\left(150^{\circ} \mathrm{E}\right)$ \\
& 28 & 36 & 45 & 48 & 38.8 & $16^{\circ} 49^{\prime} 52.5^{\prime \prime} \mathrm{S}$ \\
& 96.4 & 78.7 & 122.3 & 154.3 & 112.9 & $178^{\circ} 16^{\prime} 32.29^{\prime \prime} \mathrm{E}$ \\
$\mathrm{CTF} 1$ & $(59-156)$ & $(46-135)$ & $(80-187)$ & $(101-235)$ & & $\left(150^{\circ} \mathrm{E}\right)$ \\
& 57 & 47 & 70 & 44 & 54.5 & $16^{\circ} 49^{\prime} 56.65^{\prime \prime} \mathrm{S}$ \\
& 172.3 & 126.1 & 196.4 & 111.2 & 151.4 & $178^{\circ} 16^{\prime} 35.26^{\prime \prime} \mathrm{E}$ \\
$\mathrm{CTF} 2$ & $(120-248)$ & $(83-193)$ & $(137-281)$ & $(73-171)$ & & $\left(150^{\circ} \mathrm{E}\right)$ \\
& 42 & 111 & 63 & 122 & 84.5 & $16^{\circ} 50^{\prime} 13.52^{\prime \prime} \mathrm{S}$ \\
& 159.7 & 267.3 & 198.1 & 364.4 & 247.3 & $178^{\circ} 16^{\prime} 38.21^{\prime \prime} \mathrm{E}$ \\
& $(107-238)$ & $(202-354)$ & $(118-334)$ & $(251-528)$ & & $\left(150^{\circ} \mathrm{E}\right)$ \\
\hline
\end{tabular}

${ }^{a}$ TDF, tropical dry forest; CA, Casuarina forest; CTF, coastal tropical dry forest.

\section{Tropical Dry Forest Heterogeneity}

The three putative subtypes of tropical dry forest (tropical dry forest, coastal tropical dry forest, and Casuarina forest) were very similar when the whole data set was considered (Global $R=0.283$ ). This was due to the understory being similar in all three forest subtypes (Global $R=0.230$ ), with Diospyros spp., $M$. minutum, and $V$. amicorum dominating all subtypes (Table 2). When canopy trees were considered separately, however, the three vegetation subtypes were considerably different (Global $R=0.452$ ).

\section{Habitat Area}

The largest habitat type on Yadua Taba was tropical dry forest $(33.6 \mathrm{ha}, 46 \%$ of island [Figure 1]) followed by the rocky cliff/grassland combination (19.2 ha, 26\%). Coastal tropical dry forest vegetation covered $18 \%$ (13.5 ha) of Yadua Taba, and Casuarina forest and true coastal vegetation were poorly represented, covering only $6 \%$ (4.6 ha) and $2 \%$ (1.34 ha), respectively. Leucaena leucocephala stands covered $1 \%$ of the island $(0.9 \mathrm{ha})$.

\section{Abundance and Density of Iguanas in Each Habitat}

The abundance of iguanas on transects ranged from 11 to 122 per $250 \mathrm{~m}$ transect (Table 4). There were significantly more iguanas found on transects located in tropical dry forest and coastal tropical dry forest than in Casuarina forest (repeated measures ANOVA: habitat $F=71.04, \quad \mathrm{df}=1,3, \quad P=.004 ; \quad$ transect $F=9.311, \mathrm{df}=1,1, P=.08$; habitat ${ }^{*}$ transect $F=0.228, \mathrm{df}=1,3, P=.665)$.

The density estimates of iguanas ranged from 38 iguanas/ha in Casuarina forest to over 360/ha in coastal tropical dry forest (Table 4). On average, the density of iguanas was significantly highest in tropical dry forest followed by coastal tropical dry forest (repeated measures ANOVA: habitat $F=49.17, \mathrm{df}=$ $1,3, P<.001$; transect $F=3.581, \mathrm{df}=1,1$, $P=.155$; habitat ${ }^{*}$ transect $F=1.325, \mathrm{df}=$ $1,3, P=.334)$. Although seasonal variation in iguana density on any given transect ranged from 56 iguanas/ha (minimum 38/ha in December, maximum 94/ha in September on transect 2) to over 160 iguanas/ha (minimum 198/ha in February, maximum 364/ha 


\section{TABLE 5}

Number of Iguanas in Each Habitat Type Based on Habitat Area and Average Iguana Density in Each Habitat (Values in Parentheses Represent Range of Density Estimates for Each Habitat Type Based on Seasonal Variation)

\begin{tabular}{|c|c|c|c|}
\hline Habitat & $\begin{array}{l}\text { Habitat Area } \\
\text { (ha) }\end{array}$ & $\begin{array}{l}\text { Average Iguana } \\
\text { Density per ha }{ }^{a}\end{array}$ & No. of Iguanas \\
\hline Tropical dry forest & 33.61 & $\begin{array}{l}260.2 \\
(213-311)\end{array}$ & $\begin{array}{l}8,745.3 \\
(7,791-11,213)\end{array}$ \\
\hline Coastal tropical dry forest & 13.53 & $\begin{array}{l}199.4 \\
(111-267)\end{array}$ & $\begin{array}{l}2,697.8 \\
(1,581-3,699)\end{array}$ \\
\hline Coastal vegetation $^{b}$ & 1.34 & 111.2 & 149.0 \\
\hline Casuarina forest & 4.66 & $\begin{array}{l}84.9 \\
(38-122)\end{array}$ & $\begin{array}{l}395.6 \\
(177-569)\end{array}$ \\
\hline Rocky cliff/grassland ${ }^{c}$ & 19.20 & 0 & 0 \\
\hline Leucaena forest $^{c}$ & 0.95 & 0 & 0 \\
\hline Total & 73.29 & & $\begin{array}{l}11,987.7 \\
(9,549-15,481)\end{array}$ \\
\hline
\end{tabular}

${ }^{a}$ Based on average of two transects in each habitat all seasons combined from Table 4.

${ }^{b}$ Because no transects were exclusively in coastal vegetation, we have used the lowest density estimate for iguanas in coastal tropical dry forest (111.2 iguanas/ha, coastal tropical dry forest transect 1) as the density of iguanas in this vegetation type.

${ }^{c}$ Due to results of previous studies (Harlow and Biciloa 2001), we do not assume that there are any iguanas in these habitats on Yadua Taba.

in June on transect 5), none of these differences was significant due to the large $95 \%$ CI associated with each of the estimates.

\section{Overall Population Estimate for B. vitiensis on Yadua Taba}

Previous studies by Harlow and Biciloa (2001) did not record iguanas in over $240 \mathrm{~m}$ of transect length of grassland habitat. We took a precautionary approach of underestimating rather than overestimating the population size of B. vitiensis on Yadua Taba and therefore did not assume that there were any iguanas in the rocky cliff/grassland habitat or the Leucaena thicket. This, in conjunction with the fact that it is unlikely that we observed all $B$. vitiensis on each transect (due to their cryptic nature), ensures that our estimate is a conservative estimate of the total population size.

Our overall population estimate for iguanas on Yadua Taba is 11,987 iguanas $(95 \%$ CI 9,549-15,481 [Table 5]). The majority of these iguanas $(73 \%)$ were found in tropical dry forest habitat, followed by $22 \%$ in coastal tropical dry forest.

\section{DISCUSSION}

\section{Vegetation and Flora}

Almost $80 \%$ of the 140 vascular plant species recorded on the island were indigenous. Only 15 species were endemic to Fiji, three of which are apparently restricted to Fiji's dry zone (C. falcata, C. metallicus, and E. acuminata). Cynometra falcata is listed as Critically Endangered under current IUCN (2007) criteria, and the other two species should be considered threatened due to their restricted distribution and threats to their habitat (Keppel and Tuiwawa 2007).

Gillespie (unpubl. data, 2006) compared the species richness of tropical dry forest on several islands in Fiji. The tropical dry forest species richness of Yadua Taba (based on the Gentry transect presented here) is lower than that on or near Fiji's biggest island, Viti Levu, but is similar to that of tropical dry forest on small islands in the Yasawa Group. Although it is not surprising that a larger island would be more species rich because of its larger species pool, our data show that there are at least 10 common tropical dry forest species on Yadua Taba that were not represented in the Gentry transect, including $C$. insularis and 
Eugenia reinwardtiana, which were "abundant" (Table 3 ) in our iguana transects. This casts doubt on the ability of single belt Gentry transects as proposed by Gentry (1988) to adequately estimate species richness in tropical dry forest. In addition, its validity as a method for comparing species richness should be vigorously tested.

Although the density of 277 individual trees per transect is close to the Fijian average, the Yadua Taba tropical dry forest had the highest basal area per hectare of all Fijian tropical dry forest surveyed by Gillespie (unpubl. data, 2006). This probably reflects the presence of large, mature trees due to the low frequency of anthropogenic burning.

Tropical dry forest is heterogeneous and we distinguish, based on the composition of canopy trees, three subtypes: "true" tropical dry forest, coastal tropical dry forest, and tropical dry forest below Casuarina trees, with coastal tropical dry forest forming a broad interface between "true" coastal forest and "true" tropical dry forest. The species composition of the understory, however, was similar among the three tropical dry forest subtypes and was dominated by $V$. amicorum, M. minutum, and Diospyros species. These species are also common elements in the more diverse understory of limestone forests in higher rainfall areas (Drake et al. 1996, Franklin et al. 1999, 2008).

Of the six vegetation types recorded, only coastal vegetation (which differed on sandy and rocky shores), tropical dry forest, and rocky-cliff vegetation are natural, and Casuarina forests, grasslands, and Leucaena thickets are the result of previous fires and goat grazing. That the latter three communities are not natural is supported by them being replaced by tropical dry forest (see next section). The absence of $C$. equisetifolia seedlings in Casuarina forest with tropical dry forest species in the understory also suggests that the remnant Casuarina trees will be replaced by tropical dry forest after they die.

\section{Forest Regeneration}

Yadua Taba was most likely originally covered largely by tropical dry forest (Latham
1983, Southern 1986) and coastal forest with limited coastal scrub and rocky-cliff vegetation in the most windblown and steep, rocky areas. Grazing by introduced goats and the subsequent frequent use of fire to herd the goats substantially reduced the forest cover, resulting in large scrubland and grassland areas on the island.

Comparing our habitat map with historical maps (e.g., Gibbons 1984, Laurie et al. 1987) and aerial photographs (Fiji Department of Lands and Surveys 1994), Yadua Taba appears to be rapidly regaining forest cover. Between 1987 and 1994, less than $30 \%$ of the island was covered by tropical dry forest and coastal vegetation (Gibbons 1984, Laurie et al. 1987, Fiji Department of Lands and Surveys 1994), but today forest cover is roughly $65 \%$ (this study). The grasslands and scrublands appear to be diminishing most quickly in the central and southern sections of the island. The northern section still supports considerable areas of scrub and stands of the introduced plant L. leucocephala, and forest recovery seems slowest in this area (Raghu et al. 2005). The National Trust of Fiji in conjunction with weed specialists from Taronga Zoo, the University of New South Wales, and the villagers of Denimanu (traditional custodians of Yadua Taba) have been conducting a weed eradication program to reduce the raintree, $S$. saman, population on Yadua Taba to further improve tropical dry forest regeneration (Taylor et al. 2005).

\section{Why Are There So Many Iguanas in Tropical Dry Forest?}

Our conservative estimate of the population size of iguanas on Yadua Taba is approximately 12,000 iguanas. The majority of these iguanas were found in tropical dry forest (73\%) and coastal tropical dry forest (22\%) habitats. Previous published estimates of the population size of iguanas on Yadua Taba range from 200 (Gibbons 1981) to over 6,000 (Laurie et al. 1987, Harlow and Biciloa 2001) and also report higher abundances in tropical dry forest and coastal tropical dry forest. Few (3\%) iguanas were found in Casuarina forest with tropical dry forest un- 
dergrowth, suggesting that a closed canopy, which Casuarina does not provide, may be important for iguanas to avoid predation by Pacific harriers (Circus approximans) (Harlow et al. 2007).

Our estimate of 12,000 iguanas on Yadua Taba with an average density over the whole island of 164 iguanas/ha (in tropical dry forest the average is 270 iguanas/ha) is currently the highest recorded density for terrestrial iguanas anywhere in the world and with the exception of tuataras is possibly the highest biomass/ha of reptiles in the world (Tyrrell et al. 2000).

The high abundance of $B$. vitiensis in the tropical dry forest habitat is possibly due to the higher densities of their preferred diet plant species in this habitat. Morrison et al. (2008) conducted a survey of the diet and perch preferences of $B$. vitiensis on Yadua Taba and concluded that despite the iguanas utilizing over 30 different plant species they were primarily consuming or perching in one of 11 species. These species were $V$. amicorum, D. elliptica, M. minutum, Hibiscus tiliaceus, fasminum didymum, $M$. tiliifolius, $C$. insularis, E. reinwardtiana, $K$. platycarpum, $M$. pinnata, and $G$. americanus and were utilized in equal proportions by the different age-sex classes of iguanas. Many of these species are also abundant in limestone forest in the Lau Group (eastern Fiji [Franklin et al. 2008]) and Tonga (Drake et al. 1996, Franklin et al. 1999), where the Lauan banded iguana, $B$. fasciatus, is found.

Morrison et al. (2008) estimated the density of the 11 plant species preferred by iguanas in different vegetation types on Yadua Taba and found that the density of these species varied over the island (e.g., density of $V$. amicorum ranged from 248 to 1,400 plants/ ha) but was highest in tropical dry forest habitats. Hibiscus tiliaceus and M. pinnata were the exception and were most abundant in coastal vegetation because they are primarily coastal forest species. There was a strong correlation between plant species density and utilization by iguanas. For example, $V$. amicorum was the most common tree species on the island and was most abundant in tropical dry forest habitats. It was also the most preferred diet and perch plant species of $B$. vitiensis irrespective of iguana age or gender on Yadua Taba (Morrison et al. 2008).

The high abundance of $V$. amicorum in Yadua Taba tropical dry forest (compared with other Fijian tropical dry forest [T. Gillespie, unpubl. data, 2006]) is intriguing. Fruits of $V$. amicorum are a major dietary component of iguanas and are transported by endozoochory (Morrison et al. 2008). Although birds are also important dispersers of $V$. amicorum (Fall et al. 2007), this suggests that the iguanas are having a strong impact on the composition of the vegetation on Yadua Taba (S. F. Morrison, Australian National University, pers. comm.).

\section{Implications of Results for Tropical Dry Forest and $\mathrm{B}$. vitiensis Conservation}

The tropical dry forest of Yadua Taba is one of the least-disturbed fragments of tropical dry forest remaining in the Pacific (Keppel and Tuiwawa 2007). Although it has lower plant species richness than some other Fijian tropical dry forests (T. Gillespie, unpubl. data, 2006), the presence of threatened plant species endemic to Fijian tropical dry forests and $B$. vitiensis make it high priority for conservation. In addition, its current protected status makes it an ideal location to monitor the recovery trajectory of tropical dry forest toward its original condition before anthropogenic influences. From this monitoring, we will be able to increase our confidence in using it as a benchmark for tropical dry forest restoration and management in other sites throughout Fiji including Macuata Island, Vatia Peninsula (Viti Levu), Naicobocobo, and islands in the Yasawa Group.

The relatively good tropical dry forest habitat quality and the absence of predators including cats, dogs, and mongooses are the primary reasons for the high iguana density on Yadua Taba when compared with other Fijian islands. These factors not only influence basic individual survival (no predation) but also result in the provision of food of appropriate nutrient quality and availability, suitable vegetation structure for shelter, and soil moisture requirements for egg develop- 
ment. In addition, Yadua Taba provides seemingly ideal habitat for feeding, shelter, and reproduction of a population sufficiently large so that extreme environmental fluctuations (e.g., prolonged drought or tropical cyclones) or demographic stochasticity do not lead to extinction. As such, future translocations/reintroductions of $B$. vitiensis need to ensure that suitable tropical dry forest or coastal tropical dry forest habitat is present (to meet the requirements mentioned here) and predators are absent in translocation sites to improve the chances of translocation or reintroduction success.

The use of translocations for conservation raises a host of theoretical problems related to the ecology, population dynamics, behavior, and genetics of the species. Usually when dealing with endangered species one constraint overrides these theoretical issues: the number of translocated individuals is usually limited to minimize impacts on the source population. This should not be a major issue in translocations of $B$. vitiensis due to the large population on Yadua Taba. This is not to say that we can take as many iguanas as we want from Yadua Taba, but rather that we should (with appropriate knowledge of $B$. vitiensis population genetics and demography) be able to transfer a large enough number of individuals (essentially a minimum viable population size) to ensure that we are not compromising the success of the translocation due to constraints with population genetics and social structure, nor the security of the source population. Further research on the population dynamics and genetics of $B$. vitiensis is needed before we can determine the minimum viable population size and the minimum area of suitable habitat required for successful translocations.

Finally, it is important to understand that simply rehabilitating tropical dry forest sites and reintroducing iguanas is insufficient for the conservation management of both tropical dry forest and B. vitiensis in Fiji. Factors such as legislation, effective enforcement (e.g., use of rangers to monitor sites), fire control protocols, and long-term funding strategies are critical in the overall protec- tion of future tropical dry forest rehabilitation sites and $B$. vitiensis translocation sites throughout Fiji and must be considered in any long-term conservation plans.

\section{ACKNOWLEDGMENTS}

We thank Pita and Elesi Biciloa, Jone Niukula, Alivereti Naikatini, Marika Tuiwawa, Timaleti Vavuke, Eroni Matatia, Alma Nacuva, Eleazar O'Connor, David M. Olson, Taina Waqatabilai, William Thomas, Pita Qarau, William Waqavakatoga, Kalisi Fa'anunu, Suzie Morrison, and Zak Pierce for their valuable help in the field. Lemeki Vakausausa provided the local plant names in the plant list. We also thank the National Trust of Fiji for permission to work on Yadua Taba, the South Pacific Regional Herbarium for permission to utilize facilities for plant identification, and the villagers of Denimanu for their generous hospitality. We are very grateful to Thomas W. Gillespie, who kindly reviewed the paper and permitted us to use the Gentry transect data, which were collected under National Science Foundation (NSF) grant BCS0455052. Janet Franklin and two anonymous reviewers also provided many useful comments on the manuscript.

\section{Literature Cited}

Bright, P. W., and P. A. Morris. 1994. Animal translocation for conservation: Performance of dormice in relation to release methods, origin and season. J. Appl. Ecol. 31:699-709.

Clarke, K. R., and R. N. Gorley. 2001. PRIMER v5 user manual/tutorial. Plymouth Routines in Multivariate Ecological Research. Primer-E Ltd. Plymouth Marine Laboratories, Plymouth, United Kingdom.

Drake, D. R., A. W. Whistler, T. J. Motley, and C. T. Imada. 1996. Rain forest vegetation of 'Eua Island, Kingdom of Tonga. N.Z. J. Bot. 34:65-77.

Fall, P. L., T. D. Drezner, and J. Franklin. 2007. Dispersal ecology of the lowland rain forest in the Vava'u island group, 
Kingdom of Tonga. N.Z. J. Bot. 45:393417.

Fiji Department of Lands and Surveys. 1994. Aerial photograph of Yadua Taba Island (photo number AAM 2054/12, scale 1: 6375). Fiji Government, Suva.

Fischer, J., and D. B. Lindenmayer. 2000. An assessment of the published results of animal relocations. Biol. Conserv. 96:1-11.

Franklin, J., D. R. Drake, L. A. Bolick, D. S. Smith, and T. J. Motley. 1999. Rain forest composition and patterns of secondary succession in the Vava'u Island Group, Tonga. J. Veg. Sci. 10:51-64.

Franklin, J., G. Keppel, and W. A. Whistler. 2008. The vegetation and flora of Lakeba, Nayau and Aiwa Islands, Central Lau Group, Fiji. Micronesica 40:169-225.

Gentry, A. H. 1988. Changes in plant community diversity and floristic composition on environmental and geographical gradients. Ann. Mo. Bot. Gard. 75:1-34.

Ghazanfar, S. A., G. Keppel, and S. Khan. 2001. Coastal vegetation of small islands near Viti Levu and Ovalau, Fiji. N.Z. J. Bot. 39:587-600.

Gibbons, J. R. H. 1981. The biogeography of Brachylophus (Iguanidae) including the description of a new species, $B$. vitiensis, from Fiji. J. Herpetol. 15:255-273.

. 1984. Iguanas of the South Pacific. Oryx 18:82-91.

Griffith, B., J. M. Scott, J. W. Carpenter, and C. Reed. 1989. Translocation as a species conservation tool: Status and strategy. Science (Washington, D.C.) 245:477-480.

Harlow, P. S., and P. N. Biciloa. 2001. Abundance of the Fijian crested iguana (Brachylophus vitiensis) on two islands. Biol. Conserv. 98:223-231.

Harlow, P. S., M. Fisher, M. Tuiwawa, P. N. Biciloa, J. M. Palmeirim, C. Mersai, S. Naidu, A. Naikatini, B. Thaman, J. Niukula, and E. Strand. 2007. The decline of the endemic Fijian crested iguana Brachylophus vitiensis in the Yasawa and Mamanuca archipelagos, western Fiji. Oryx 41:4450.

Henderson, P. A., and R. M. H. Seaby. 2002. Community analysis package. Version 2.15.
PISCES Conservation Ltd. Pennington, Lymington, Hants., United Kingdom.

IUCN. 2007. IUCN Red List of Threatened Species. Available at http://www .iucnredlist.org.

IUCN Species Survival Commission. 2008. Fijian Crested Iguana, Brachylophus vitiensis, species recovery plan 20082012 (in press). Available from www .iguanafoundation.org/downloads.

Janzen, D. H. 1988. Tropical dry forest-the most endangered major tropical ecosystem. Pages 130-137 in E. O. Wilson and F. M. Peter, eds. Biodiversity. National Academy Press, Washington.

Keogh, J. S., D. L. Edwards, R. N. Fisher, and P. S. Harlow. 2008. Molecular and morphological analysis of the critically endangered Fijian iguanas reveals cryptic diversity and a complex biogeographic history. Phil. Trans. R. Soc. B. 363:34133426.

Keppel, G. 2005. Fiji's tropical dry forest-an ecosystem on the brink of extinction. Melanesian Geogr. 3:22-25.

Keppel, G., and M. Tuiwawa. 2007. Dry zone forest in Fiji: Species composition, life history traits and conservation. N.Z. J. Bot. 45:454-463.

Latham, M. 1983. Origin of the talasiga formation. Pages 129-141 in M. Latham and H. C. Brookfield, eds. The eastern islands of Fiji. UNESCO/UNFPA, Paris, France.

Laurie, W. A., H. Uryu, and D. Watling. 1987. A faunal survey of Yaduataba Island reserve with particular reference to the crested iguana (Brachylophus vitiensis Gibbons 1981). Domodomo 5:16-28.

Lerdau, M., J. Whitbeck, and N. M. Holbrook. 1991. Tropical deciduous forest: Death of a biome. Trends Ecol. Evol. 6:201-202.

Meyer, J.-Y. 2000. Preliminary review of the invasive plants in the Pacific Islands (SPREP member countries). Pages 85114 in G. Sherley, ed. Invasive species in the Pacific: A technical review and draft regional strategy. South Pacific Regional Environment Programme, Apia, Samoa. 
Mooney, H. A., S. P. Bullock, and E. Medina. 1998. Introduction. Pages 1-8 in S. P. Bullock, H. A. Mooney, and E. Medina, eds. Seasonally tropical dry forest. Cambridge University Press, Cambridge, United Kingdom.

Morrison, C. 2003. A field guide to the herpetofauna of Fiji. Institute of Applied Sciences, University of the South Pacific, Suva, Fiji.

Morrison, C., T. Osborne, P. S. Harlow, N. Thomas, P. Biciloa, and J. Niukula. 2008. Diet and habitat preferences of the Fijian Crested Iguana (Brachylophus vitiensis) on Yadua Taba, Fiji: Implications for conservation. Aust. J. Zool. 55:341-350.

Mueller-Dombois, D., and H. Ellenberg. 2002. Aims and methods of vegetation ecology. Blackburn Press, New Jersey.

Mueller-Dombois, D., and F. R. Fosberg. 1998. Vegetation of the tropical Pacific islands. Springer Press, New York.

NBSAP. 1998. Fiji national biodiversity strategy and action plan. Fiji Government, Suva.

Olson, D. M., M. Tuiwawa, J. Niukula, P. Biciloa, G. Keppel, A. Naikatini, B. Thaman, and L. Vakausausa. 2002. Conservation of Fijian dry forest and Fijian crested iguanas on Yadua Taba Island. Wildlife Conservation Society, Suva, Fiji.

Pregill, G. K., and D. W. Steadman. 2004. South Pacific iguanas: Human impacts and a new species. J. Herpetol. 38:15-21.
Raghu, S., C. Wiltshire, and K. Dhileepan. 2005. Intensity of pre-dispersal seed predation in the invasive legume Leucaena leucocephala is limited by the duration of pod retention. Aust. Ecol. 30:310-318.

Smith, A. C. 1979-1991. Flora Vitiensis nova: A new flora of Fiji (spermatophytes only). Vol. 1-5. Pacific Tropical Botanical Garden, Lāwa'i, Kaua'i, Hawai'i.

Southern, W. 1986. The Late Quartenary environmental history of Fiji. Ph.D. thesis, Australian National University, Canberra.

Taylor, J. E., P. S. Harlow, and J. Niukula. 2005. Invasive plant assessment and weed management plan for the Fijian Crested Iguana Sanctuary Island of Yadua Taba, Bua. Unpublished report for the National Trust of Fiji. Available from the National Trust of Fiji.

Thomas, L., J. L. Laake, S. Strindberg, F. F. C. Marques, S. T. Buckland, D. L. Borchers, D. R. Anderson, K. P. Burnham, S. L. Headley, J. H. Pollard, and J. R. B. Bishop. 2004. Distance 4.1, Release 2. Research Unit for Wildlife Population Assessment, University of St. Andrews, United Kingdom.

Tyrrell, C. L., A. Cree, and D. R. Towns. 2000. Variation in reproduction and condition of northern tuatara (Spbenodon punctatus punctatus) in the presence and absence of kiore. Science for Conservation 153. Department of Conservation, New Zealand. 


\section{Appendix}

Vascular Plants of Yadua Taba Island, Fiji

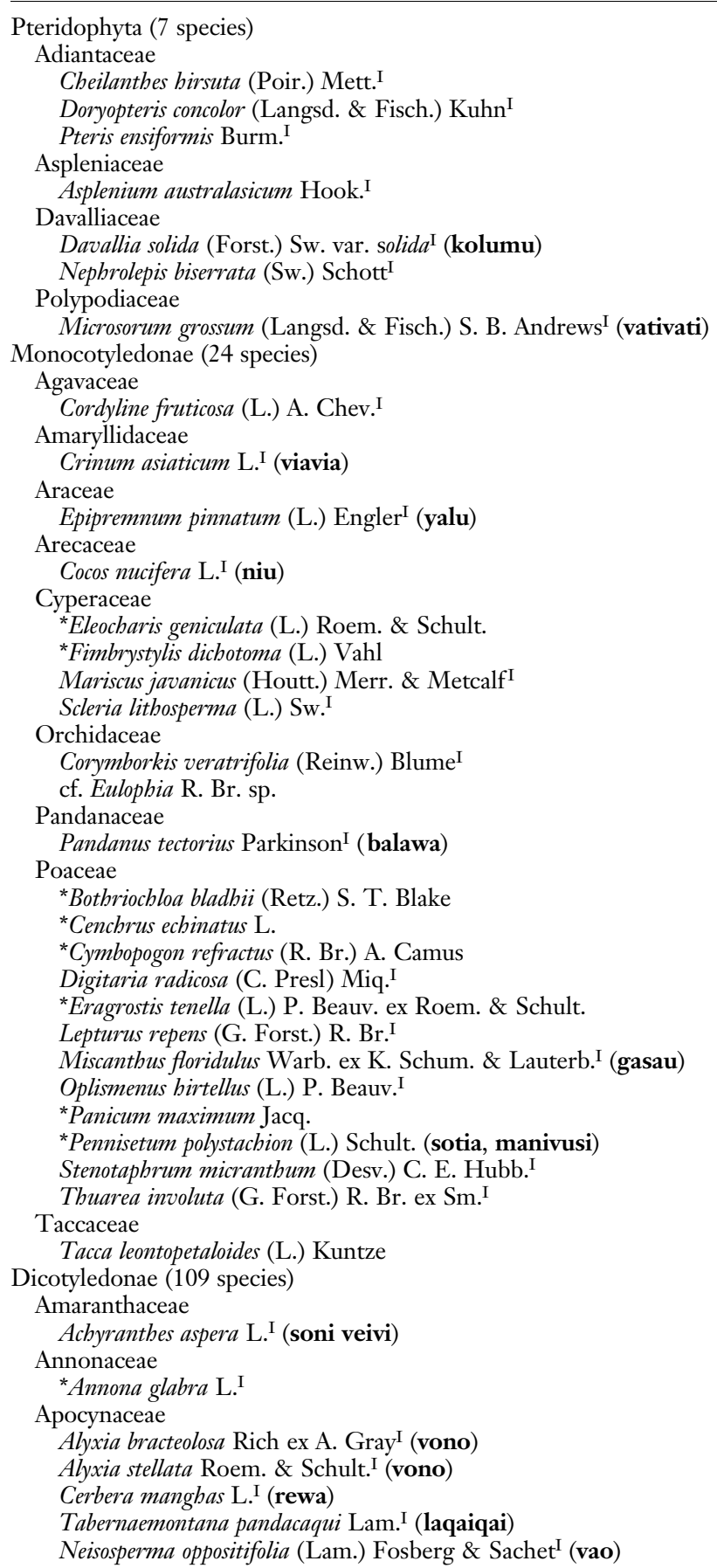


Appendix (continued)

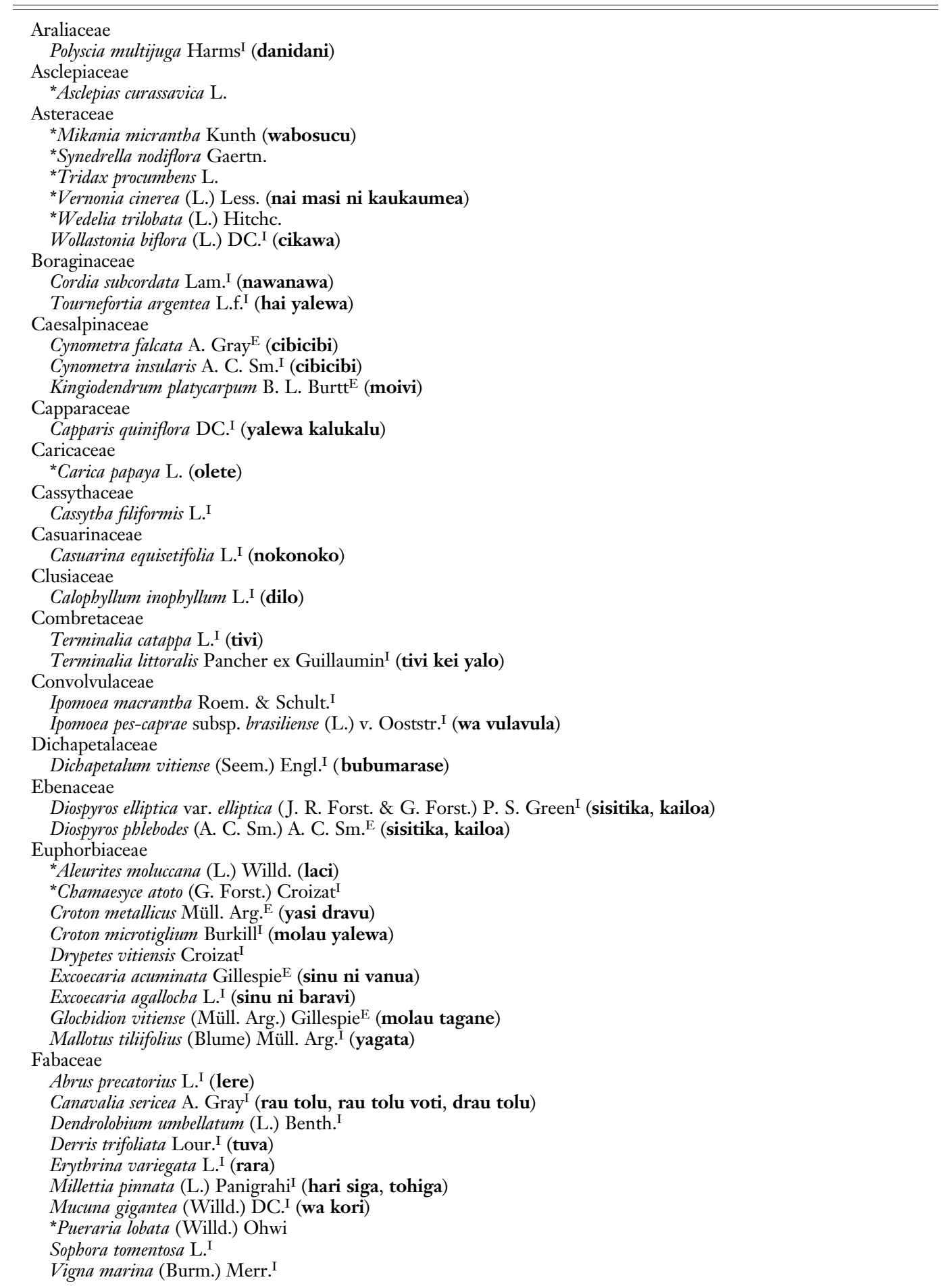


Appendix (continued)

Flacourtiaceae

Casearia richii $\mathrm{A}$. Gray ${ }^{\mathrm{E}}$

Homalium vitiense Benth. ${ }^{\mathrm{E}}$

Goodeniaceae

Scaevola taccada (Gaertn.) Roxb. I (dreidrei)

Hernandiaceae

Gyrocarpus americanus Jacq. ${ }^{\mathrm{I}}$ (wiriwiri)

Hernandia nymphaeifolia (Presl) Kubitzki ${ }^{\mathrm{I}}$ (evuevu)

Lecythidaceae

Barringtonia asiatica (L.) Kurz ${ }^{\mathrm{I}}$ (vutu)

Malvaceae

Hibiscus tiliaceus L. (vau)

Thespesia populnea (L.) Correa ${ }^{\mathrm{I}}$ (mulomulo)

${ }^{*}$ Urena lobata $\mathrm{L}$.

Meliaceae

Vavaea amicorum Benth. ${ }^{\mathrm{I}}$ (cevua)

Xylocarpus moluccensis (Lam.) M. Roem. ${ }^{\mathrm{I}}$ (leqileqi)

Mimosaceae

Acacia simplex (Sparrman) Pedley (tataqia)

Entada phaseoloides (L.) Merr. ${ }^{\mathrm{I}}$ (wa tiqiri)

*Leucaena leucocephala (Lam.) de Wit (vaivai)

*Samanea saman (Jacq.) Merr. (vaivai mocemoce)

Moraceae

Ficus barclayana (Miq.) Summerh. ${ }^{\mathrm{E}}$ (losilosi)

Ficus obliqua G. Forst. ${ }^{\text {I }}$ (baka, baka ni Viti)

Ficus tinctoria G. Forst. (baka, baka ni Viti)

Streblus anthropophagorum (Seem.) Corner ${ }^{\mathrm{I}}$

Myrsinaceae

Maesa persicifolia A. Gray ${ }^{\mathrm{E}}$ (bubumeirase)

Maesa tabacifolia Mez

Myrtaceae

Decaspermum vitiense (A. Gray) F. Niedenzu ${ }^{\mathrm{E}}$ (nuqanuqa)

Eugenia reinwardtiana DC. (kinikoro, qaqikoro)

${ }^{*}$ Psidium guajava L. (quava)

Olaceae

Ximenia americana L.I (homuhomu)

Oleaceae

Jasminum didymum subsp. didymum G. Forst. ${ }^{\mathrm{I}}$ (gasau cebucebu)

Zasminum simplicifolium G. Forst. ${ }^{\mathrm{I}}$

Oxalidaceae

*Oxalis corniculata $\mathrm{L}$. (rogomi, matakonikoni)

Passifloraceae

${ }^{*}$ Passiflora foetida L. (poro matila)

*Passiflora suberosa L.

Pittosporaceae

Pittosporum brackenridgei A. Gray ${ }^{\mathrm{I}}$ (duva kalou)

Rhamnaceae

Colubrina asiatica (L.) Brongn. I (vere)

Ventilago vitiensis A. Gray ${ }^{\mathrm{I}}$ (vere)

Rhizophoraceae

Rhizophora stylosa Griff. $^{\mathrm{I}}$

Rubiaceae

Antirbea inconspicua (Seem.) Christoph. (bobo damu)

Coprosma persicifolia A. Gray ${ }^{\mathrm{E}}$

Guettarda speciosa L.I (buabua)

Morinda citrifolia L.I (kura)

Psychotria tephrosantha A. Gray ${ }^{\mathrm{E}}$

Psydrax odorata (G. Forst.) A. C. Sm. \& S. P. Darwin ${ }^{\mathrm{I}}$ (noko ni savu)

*Spermacoce assurgens Ruiz \& Pav. 
Appendix (continued)

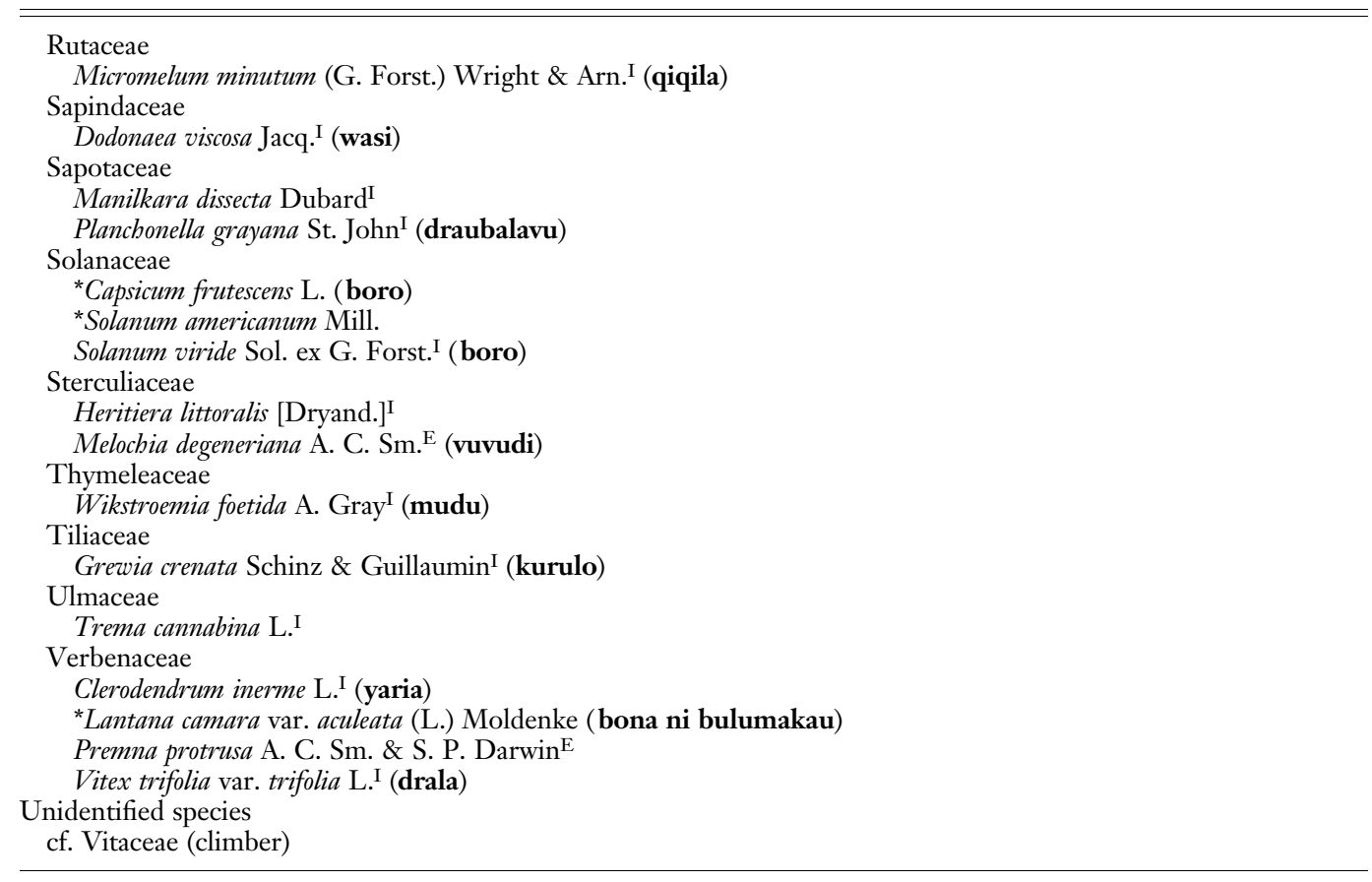

Note: A more detailed list can be obtained from the authors. Names in boldface in parentheses after botanical name are plant names used in Denimanu village.

${ }^{*}$, introduced; I, indigenous; $\mathrm{E}$, endemic. 